\title{
The Process of Implementing Divorce Cases in North Sumatra Religious Court after the Entry into force of PERMA Number 1 of 2016
}

\section{Rusli Halil Nasution, Asmuni, Pagar Hsb}

Islamic Law Study Program, Universitas Islam Negeri Sumatera Utara, Indonesia

\begin{abstract}
The aims of the study are to find out the process of implementing divorce case in North Sumatera. This study is a qualitative and normative study of PERMA Number 1 of 2016 with its application in the North Sumatra Religious Court as a legal product in the present aspects that applies in testing the success of the regulation being implemented in the North Sumatra Court, especially in (three) 3 big cities namely the Court Medan, Binjai and Tebing Tinggi religion. The result shows that The implementation of peace in divorce cases in the North Sumatra Religious Court is not significant. In the implementation of divorce case mediation in the North Sumatra Religious Court, many factors influence, among others, technical and nontechnical factors. The technical factor is the limitations of the Mediator, namely the absence of a list of non-Judge Mediators here will further aggravate the work of the Judge because of his work being double that is as a Panel Judge and Mediator Judge. So that the work of the Judge mediator is very ineffective and so is the non-judge mediator who must have an official certificate from the Supreme Court so that the training costs are large and the costs of the mediator are not protected by the Regulation
\end{abstract}

Keywords services, administration, regional office ministry of religion

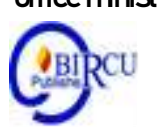

\section{Introduction}

Getting married is one phase of life that is commonly done by every adult human, ready physically and mentally, and has a sense of responsibility in building a household. Every person who has fulfilled these requirements is recommended to set his feet to the level of marriage. It is this level that marks a phase of life that is very important for one's survival in the future. Compared to living alone, family life has many challenges and also contains a number of positive expectations. No doubt in marriage there are many benefits if you can manage it well. (Surya, 2019)

The Supreme Court has changed the paradigm of adjudicating into a paradigm of resolving legal cases disputes. Settlement of civil case disputes through litigation began to be abandoned and turned to Alternative Dispute Resolution / ADR (mediation). The manifestation of this change was by issuing PERMA Number 2 of 2003, and then revised through PERMA Number 1 of 2008 and subsequently revised by PERMA Number 1 of 2016, concerning Mediation Procedures in the courts of the Supreme Court of the Republic of Indonesia. This government step has resulted in developed countries that have successfully resolved disputes through mediation, such as Japan, Singapore, Canada, the United States, the Netherlands and Australia. 
The court as one of the law enforcement instruments has carried out the Peace for a long time so that the issuance of sagat regulations was felt until recently in PERMA No. 1 of 2016 , but the outcome of the peace is still below 2\%. This shows that the integration of peace in the legal system in the North Sumatra Religious Court has not been successful. This success should not be relied on law enforcement but must have mutual support between law enforcement and legal culture, law enforcement will be able to run well if the legal principle must be good and clear, and the public obedient to the law, if it is not very supportive then law enforcement becomes unsuccessful

The teachings in Islam are very multi and complete. Whether it is related to personal and social, in it many rules and laws that governs in all lines of life of Muslims. Allah Almighty with the book he has revealed for humans is proof that this religion is not a religion that was created and formulated by humans. The Koran contains many directions and instructions for humans is a choice for humans, whether they want to believe or still keep on stirring. Because in the Koran there is a picture of people who are fortunate because they believe in Him, and also those who are wretched because they disbelieve in Him.

Judicial decisions have played a role in the renewal of Islamic law both at the national and international levels. One of the reasons the court's decision played a role in the renewal of Islamic law is because the legal material in fiqh is no longer appropriate when applied in a case that is requested to be resolved by the court, while the qānun (statutory regulation) has regulated, but is incomplete or completely unregulated, even though the need is very urgent. Therefore, the judge by means of jijtihad decides the case submitted.

Before elaborating on the Supreme Court Regulation No. 1 of 2008 concerning Courtconnected Mediation Procedures, it is also necessary to explain the background why the Supreme Court of the Republic of Indonesia (hereinafter abbreviated as MARI) requires the use or completion of mediation before a case is decided by a judge based on Regulations Supreme Court Number 2 of 2003 and PERMA Number 1 of 2008 which were subsequently replaced and declared invalid by Supreme Court Regulation Number 1 of 2016.

MARI's policy of applying mediation to litigation in court can be seen from the considerations formulated in the Consideration of Supreme Court Regulation No. 2 of 2003 and Supreme Court Regulation No. 1 of 2016.

The first consideration is that the use of mediation is expected to overcome the problem of case buildup. If the parties themselves can settle a dispute without having to be tried by a judge, then the number of cases that must be examined by the judge is reduced too. If the parties can resolve the dispute through peace, then the number of cases that rise to the cassation process will also decrease because peace is the result of the mutual will of the parties, so the parties will not submit efforts to fight the law.

Conversely, if a case is decided by a judge, then the decision is the result of the judge's views and judgments about the facts and the legal position of the parties. Judges' views and judgments are not necessarily in line with the views of the parties, especially the losing parties, so that the losing parties always hold legal resistance through appeals and appeals. In the end, all cases ended in MARI which resulted in the accumulation of cases in MARI.

Second, the mediation process is seen as a way to settle disputes that is faster, and cheaper, than the judging process. In Indonesia, there are no studies that prove the assumption that mediation is a quick and inexpensive process compared to the process of deciding by a judge. However, if based on logic as described in the first reason that if the case is decided, the losing party often submits legal resistance, appeal or cassation, so making a settlement of the case may take decades, since the first level of examination in District Court up to the examination of the cassation level at MARI. 
Conversely, if a case can be resolved with peace, then the parties themselves can accept the final result because it is the result of their work that reflects the mutual will of the parties. In addition to the logic as described, the literature often states that the use of mediation or other forms of resolution that are included in the definition of alternative dispute resolution (ADR) is a process of resolving disputes that is faster and cheaper than the judging process.

Third, the application of mediation is expected to expand access for the parties to obtain a sense of justice. The sense of justice can be obtained not only through the process of deciding by a judge, but also can be achieved through a process of consensus agreement by the parties. With the introduction of mediation in the formal justice system, justice seekers in general and disputing parties in particular can first seek to resolve their disputes through a consensus approach which is assisted by a mediator or mediator.

From the pre-research data that the author did in the Religious Courts, after PERMA No.1 of 2016 concerning Mediation Procedures in the Court on February 4, 2016, there has been a fundamental change in the practice of Religious Courts in Indonesia. The court does not only have the duty and authority to examine, hear and settle the case it receives, but also has the obligation to seek peace between the parties in particular in the first trial process. However, because the relationship between husband and wife who has litigated in court has been very severe, their hearts have been broken, the peace efforts so far have not brought much satisfying results to the litigation community.

From the cases that entered the Religious Courts throughout North Sumatra after the enactment of Supreme Court Regulation (PERMA) No.1 of 2016. that cases received in 2019 in all PA authority cases amounted to 16,416 in the field of divorce cases totaling 13,339 or $81.26 \%$, while cases outside of divorce handled by PA amounted to 3,077 or $18.26 \%$. while for the divorce divorce case (CT) numbered 2,837 , or $21.27 \%$ while the divorce case (CG) 10.502 . or $78.73 \%$. The divorce rate above is really very alarming, because if we compare it with the number of events. While the case is revoked. This means that only $5.2 \%$ have succeeded in peace or reconciliation.

From the background of this problem, the author wishes to examine it which focuses on optimizing business and the role of mediators in resolving cases in the North Sumatra Religious Court, because of this, the authors are interested in researching. this issue into a dissertation with the title: "The Process of Implementing Divorce Cases in North Sumatra Religious Court After the Entry into force of PERMA Number 1 of 2016".

\section{Review of Literature}

\subsection{Peace}

Based on Article 131 Paragraph 1 Het Herziene Indonesisch Reglement (HIR), efforts to reconcile are imperative. That the judge is obliged to try to reconcile the parties to the litigation, and if it is not carried out then the consequences of the decision will be null and void. This also applies in divorce cases, where peace efforts are imperative that judges must be carried out effectively and optimally in every trial, especially in divorce cases on the grounds of disputes and quarrels.

The judge finds as much as possible the background of the dispute and the causal factors of the problem between the parties. If in the examination of divorce cases for reasons of disputes and squabbles the judge does not try to be optimal, then the examination and decision can be null and void by law or can be canceled because it is deemed not fulfilled the procedural rules. However, the obligation to reconcile will be different if in divorce cases 
with other reasons, such as reasons for adultery, disability, or the soul that results in non-performance of obligations. Efforts to reconcile cannot be prosecuted optimally because these efforts are made by judges only as a moral obligation and not a legal obligation.

The purpose of peace efforts in divorce cases is to influence those who originally wanted divorce to think again and decide to withdraw the lawsuit that has been submitted to the Court so that divorce does not occur. Then, peace efforts are also carried out in order to realize the ideal goal of marriage based on Law No.1 of 1974, namely to form a happy and eternal family based on the Godhead of the Almighty. In addition, as a form of the creation of the principle complicates divorce as contained in the general explanation of item 4 letter e of Law No. 1 of 1974, namely: "because the purpose of marriage is to form a family that is eternally happy and prosperous, this law adheres to the principle of making divorce difficult. To allow divorce, there must be certain reasons and must be done before a court hearing ".

\subsection{Peace in Islam}

In the history of Islamic civilization, peace is known by the word sulhu which means to break off or resolve disputes or peace. The term sulhu is found in fiqh literature which deals with matters of transactions, marriage, war, and rebellion. Meanwhile, according to the term, sulhu is defined as a contract that is determined to resolve a fight.

In Islam peace is known as al-islah which means repairing, reconciling and eliminating disputes or damage, trying to create peace, bringing harmony, encouraging people to make peace between one another and doing good deeds behaving as saints. The Qur'an explains that Islah is an obligation of Muslims both personally and socially. The emphasis of this islah is more focused on the relationship between fellow human beings in the context of fulfilling obligations to Allah SWT.

The legal basis for allowing peace or mediation in Islam includes several verses in the Koran, namely:

1) Surah Al-Hujurat verses 9-10:

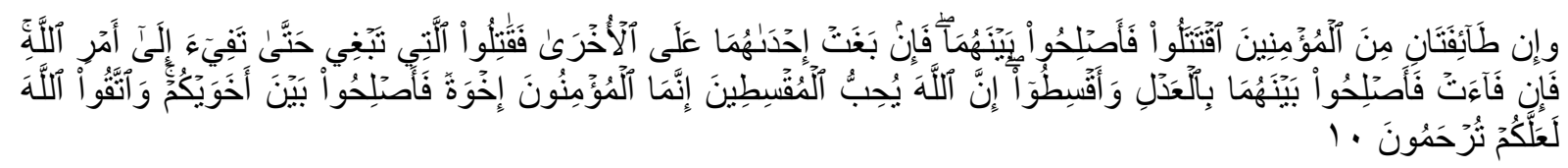

Meaning: And if there are two groups of those who believe in war, you must reconcile between the two, but if one violates the Covenant against the other, let that violate the Covenant you fight until it recedes back to God's command. if he has receded, reconcile between them according to justice, and let you act justly, surely Allah loves those who apply justly. Believers are indeed brothers and sisters. therefore reconcile (improve the relationship) between your two brothers and fear God, so that you may receive mercy.

2) Surah an-Nisa 'verse 35:

Family problems if there are disputes should not be allowed to be prolonged must be reconciled, the Koran calls it a judge as in surah an-Nisa 'verse 35:

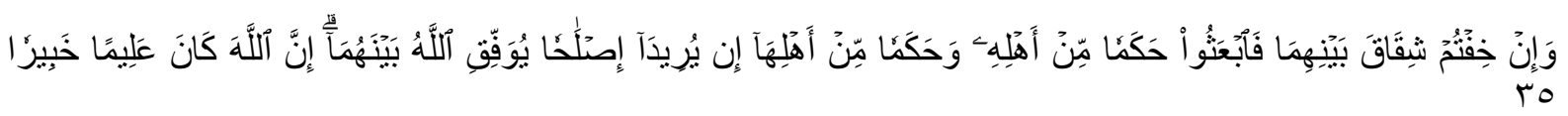

Meaning: And if you are worried about a dispute between the two, then send a hakamdd from a family of men and a hakam from a female family. if the two hakam people intend to make improvements, surely Allah gave taufik to the husband and wife. Verily, Allah knows best. 
The above verse shows if it is feared that there will be divisions between the two parties that violate the limits set by God, it can be corrected by mediation (tahkim). Both parties may send a hakam, who represents each of them, who knows well about the problem at hand. If there is no one from each family, may be taken from someone else. Both of the appointed hakam work to improve the situation of both parties, so that the muddy becomes clear, and the cracked does not break and no less important does not happen that are not desirable (murder).

3) Surah an-Nisa 'verses 114 and 128:

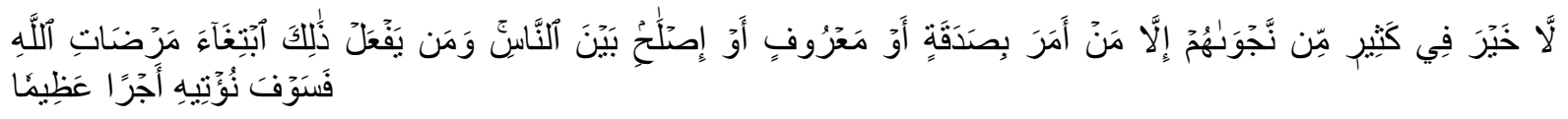

Meaning: There is no kindness to most of their whispers except whispers from people who tell people to give alms or do good things or make peace between people and whoever does so for seeking the pleasure of Allah, then we will give him a great reward

\subsection{PERMA Number 1 of 2016}

PERMA Number 1 Year 2008 cannot be used as a permanent regulation, due to the development of existing problems that require refinement which results in the revision of the PERMA. On February 4, 2016, the Supreme Court issued PERMA Number 1 of 2016 as a perfect PERMA Number 1 of 2008. Chapter IX of the Closing Provisions of Article 38 of this PERMA confirms:

When the Supreme Court Regulations came into force, Supreme Court Regulation No. 1 of 2008 concerning Mediation Procedures in the Court was revoked and declared invalid.

PERMA Number 1 of 2016 entitled "Mediation Procedures in the Court as a revision with a view to making more effective use of mediation that is more useful and able to increase the success of mediation in the Court related to the case process in the Court, with substance consisting of IX Chapters and 39 Articles, namely:

- Chapter I: General Provisions (Article 1)

- Chapter II: Guidelines for Mediation in Courts (Articles 2-12)

- Chapter III: Mediators (Articles 13-16)

- Chapter IV: Pramediation Stage (Articles 17-23)

- Chapter V: Stages of the Mediation Process (Articles 24-32)

- Chapter VI: Voluntary Peace (Articles 33-34)

- Chapter VII: Separation of Mediation from Litigation (Article 35)

- Chapter VIII: Peace Outside the Courts (Articles 36-37)

- Chapter IX: Closing Provisions (Articles 38-39)

\section{a. Reasons for the issuance of PERMA}

In the consideration, it was stated several reasons behind the issuance of Perma, replacing SEMA No. 1 of 2002, including:

1. Overcoming the Case Stacking In point a considerations put forward the thought:

a) An effective instrument needs to be created that is able to overcome the possibility of a case buildup in court, of course especially at the cassation level.

b) According to PERMA, the instrument considered effective is the mediation system, and

c) How, by integrating mediation into the justice system. This system is the same as court connected mediation developed in several countries, such as America, Australia, and so on. 
2. Low cost or minimum (zero cost), basically almost does not require costs compared to the litigation or arbitration process which costs are relatively cheaper (expensive) or very expensive (very exvensive).

3. Can provide access to the disputing parties to obtain justice or can provide a more satisfactory solution to the dispute resolution, because the settlement prioritizes the humanitarian and fraternal approach based on negotiations and agreements rather than the legal and bargaining power approaches.

\subsection{Termination of Marriage in Court. Religion}

The termination of the marriage and its consequences contained in Chapter VIII Article 39 paragraph 2 of Law No.1 of 1974 stipulates that in order to divorce there must be sufficient reasons that between husband and wife will not be able to live in harmony as husband and wife. Based on the provisions of article 39 paragraph 2 of Law No. 1 of 1974, the reason for divorce is based solely on the impossibility of achieving harmony between husband and wife in a domestic life. However, the reason is actually clarified again in the article by article explanation of article 39 paragraph 2 of Law No. 1 of 1974 which is then reiterated in article 19 of PP No. 9 of 1975, in the explanation there are several events that can be used as reasons for divorce which the same as what was explained in 1974.

The purpose of marriage is to create a happy and eternal family. The sublime goal basically will always be intended by the couple who hold a marriage, even with the prayer of the two camps of the family or the surrounding community. It is his nature that nothing in this mortal world is eternal, including marriage. At a certain time every marriage will surely break up or break up. This is confirmed by Article 38 of the Marriage Law which states:

Marriage can be broken because:

1. Death

2. Divorce

3. by court decision.

Dismissing a divorce due to one of the parties being absent and then followed by a new marriage for those left behind, this reason in the past one and a half years was indeed worth noting because the level of advancement in information technology at that time was still not as advanced as it is now. New marriages for those left behind, can be carried out after court intervenes regarding the circumstances of one husband or wife (Article $494 \mathrm{BW}$ ). The role of the court is crucial to be able to carry out a new marriage for the party left behind, so that the process in accordance with the rules must be fulfilled and monitored. The judge's hand is the determinant for the dissolution of an old marriage and then a new marriage.

The dissolution of marriage after the separation of the table or bed was indeed possible by BW due to the influence of religious teachings which were later modified. In Article 200 BW the period of time between table and bed is set at 5 (five) years without peace between the husband and wife concerned. The reason for the dissolution of a marriage based on separate tables and beds, the role of the court was also very obvious. The intervention of the judge in accordance with the procedure is very strong, and this proves that the effort to complicate the divorce is as optimal as possible.

Based on the reasons for the dissolution of the marriage due to reasons of absence from one of the parties also due to the separation of the table and the bed, both of them were indeed stipulated by law, but the court continued to guard closely in accordance with applicable procedures. The two kinds of causes for the dissolution of marriage, the judge becomes the determinant, means that both are classified in similar categories. This pattern is in accordance with the structure of Dutch society based on time and influence of religious 
teachings. However state interference through the hands of judges, it is still enforced that the dissolution of a marriage is not misused.

Regarding the termination of marriage after being preceded by a separate table and bed, this reason is not well known in the Marriage Law, so it is questionable whether this institution is permitted if the word is used now if a couple requests a court. If indeed the purpose of the marriage law, among others, is to avoid divorce optimally, there is no harm in separating the tables and beds, such as asking for local pengadialan. The methods and procedures in BW can be adopted by the judge through his authority in the effort to exchange divorce. which is mandated by the Marriage Law. Regarding the duration of the separation of the table and the bed must be how long, do not need to imitate for 5 (five) years like BW, enough to be able to use a period of 2 (two) years as is known for reasons of divorce in the Marriage Law. Adopting a separate desk and bed institution with a change in time period, would not violate the principles of Indonesian Marriage law.

\section{Research Method}

This study is a qualitative and normative study of PERMA Number 1 of 2016 with its application in the North Sumatra Religious Court as a legal product in the present aspects that applies in testing the success of the regulation being implemented in the North Sumatra Court, especially in (three) 3 big cities namely the Court Medan, Binjai and Tebing Tinggi religion.

The translation research of the English, some experts who translate research. Research itself comes from the word re, which means back and to research which means to look back. As the prevalence of a library research that is supported by some field data will be put forward performance in an effort to find conclusions that are right on target and satisfying. Because of the above it will be described later, such as the type of research, data sources, data techniques, data collection techniques and data techniques through observation, interviews and analysis of existing documents at the office of the Ministry of Religion in Aceh Province.

\section{Result and Discussion}

\subsection{The Process of Implementing Peace in Divorce Cases in the Uatara Sumatra Religious Court}

In the implementation of divorce case mediation in the North Sumatra Religious Court, many factors influence, among others, technical and non-technical factors. The technical factors are the first: the limitations of the Mediator, namely the absence of a list of non-Judge Mediators here will further burden the work of the Judge because his work is double namely the Panel Judge and the Mediator Judge. In fact, having a list of Mediators here will make it easy for the parties to the dispute to choose a Mediator who will assist him in resolving disputes through mediation. The more the number of mediators in court the better, because the parties will have many choices of mediators, so that the right mediator will be found, have expertise and are able to help resolve their disputes.

There is no non-Judge Mediator, and those who play a role there are the Judges of the Courts themselves, who do not necessarily have the ability to mediate, because mediators require Mediators who are trained and educated by professional institutions. The skill will determine the success or failure of a Mediator to resolve a dispute between the parties. Bearing in mind the Mediator's role greatly determines the effectiveness of the dispute resolution process, the Mediator in the North Sumatra Religious Court must meet certain requirements and qualifications. The requirements for a Mediator can be seen from two sides, 
namely the Mediator's internal side and the Mediator's external side. The internal side relates to the mediator's personal ability to carry out his mission of bridging and regulating the mediation process, so that the parties successfully reach an agreement that can end their dispute. The external side relates to the formal requirements that must be had by the Mediator in relation to the dispute he is handling. He simply wants to show concern that disputes that are not resolved will bring negative impacts, not only to individuals, but also the community (social). The mediator only helps the parties to end the dispute, bearing in mind that every human being naturally wants to be free from conflict and dispute. The mediator in facilitating and negotiating between the parties to the dispute does not side with one of the parties. It is neutral in carrying out the mediation process, as is fair in giving the parties the opportunity to raise their concerns. The mediator does not take any actions or remarks that cause an unfair feeling from one party.

Most of the information given by Judge Sri Armaini at the Binjai Religious Court was not yet certified by the Mediator. Although a judge who is a mediator is not a judge who is a certified mediator, here must see the extent to which the judge is able to carry out his duties or the limited skills of the judge to mediate, which mediation here requires a number of skills (skills) that must be sharpened, so that it will facilitate the resolution of disputes between the parties through peaceful channels or mediation. Because remembering the cases that were resolved through peaceful efforts were very limited which were successfully carried out. So judge training.

The first stage that must be carried out by the Judge in hearing a case presented to him is to seek peace between the parties who are litigants. That is by way of mediation, which requires that the Judge before proceeding with the proceedings of the case first offer mediation to the disputing party. This offer is not a form of choice but must be followed by the parties. On the first hearing that was attended by both parties, the judge required the litigants to take mediation first. This stipulation showed that the parties could not refuse the obligations imposed on the Judge to take the mediation path first before the case continues. Before the mediation process is carried out, the Judge is obliged to provide an explanation to the parties regarding the mediation procedure and costs. This is important so that the parties can know the mechanisms, procedures and costs of mediation that must be spent in the mediation process. The parties can choose the Mediator available in the list of Mediators in the Court, both Mediators who come from Judges and Mediators who come from non Judges. If the parties appoint a Mediator who comes from a Judge, then the parties are not charged any fees, whereas if the parties appoint a Mediator who is from a non-Judge, then the parties must pay the Mediator services, the amount of which depends on the agreement.

In the North Sumatra Religious Court the peace process by mediation based on PERMA No. 1 of 2016 concerning mediation mediation procedures in the Court is expected to be more optimal, practical and not protracted in reconciling parties involved in litigation. The mediation process in the Religious Courts North Sumatra is going well. In the technical selection of mediators in the North Sumatra Religious Court in accordance with PERMA Number 1 regarding mediation procedures in the Court. In the Court, a list was prepared in accordance with the Supreme Court, the parties chose the Mediator, then they presented to the Panel of Judges, then the Panel of Judges would appoint a Judge who was not on trial that day. Most of North Sumatra has not been certified by a Mediator and there is no list of nonJudge Mediators, which is increasingly burdensome for the work of the Judge because the work will become double. Namely as the Panel of Judges and as a Mediator. This will affect the performance of the Judge as a Mediator ie the Judge of the Mediator cannot be totally and sincerely in carrying out the mediation process. The more number of mediators in the North Sumatra Religious Court the better because the parties will choose many Mediator choices, so 
that the right Mediator will be found, has expertise and is able to assist in resolving their disputes.

This mediation regulates how peaceful procedures are assisted by a neutral party namely a Mediator. Mediators can develop and offer dispute resolution options and the parties can also consider the Mediator's offer as an alternative to an agreement in dispute resolution. Alternative solutions offered by the Mediator are expected to be able to accommodate the interests of the parties to the dispute. Mediation can bring the parties to reach an agreement without feeling there is a party that wins or there is a party that loses (win-win solution).

And there is special attention by Law No. 3 of 2006 in family disputes (divorce) cases that follow one of the principles of Law No.1 of 1974 concerning marriage, namely the divorce process is complicated, because it contains principles that aim to guarantee the noble ideals of marriage, namely, forming a family, a home a happy and eternal ladder based on the Godhead. So as to realize these goals, it takes a basic principle which is a rule for always maintaining everything that can make the main goal failing, including all the causes that can cause disputes in marriage such as nushuz, i'radh, or lack of harmony in everyday relationships. it is a tabi'at that cannot be eliminated in human life.

This mediation procedure is very suitable to be applied in every civil case that enters the North Sumatra Religious Court because the mediation procedure regulates matters concerning the process towards peace. As revealed by Sri Armaini MH, one of the Judges at the North Sumatra Religious Court, It is hoped that this PERMA peace effort will be more optimal and can reduce the accumulation of cases in the Court, especially the North Sumatra Religious Court.

Perma No. 1 of 2016 concerning mediation to show the significant value of mediation, hence it is often associated with Article $130 \mathrm{HIR}$ and $154 \mathrm{RBg}$. This article is part of the procedure for solving civil disputes. In this Article there is a demand (obligation) for the Judge to seek peace. Without this effort, any decision to be reached is considered null and void by law. With this reasoning, mediation becomes mandatory or mandatory.

In the implementation of Perma No. 1 of 2016 concerning mediation, it could not be carried out optimally, especially in divorce cases. What is clear is this is caused by several factors, inhibiting factors or causes of mediation in the success of divorce cases in the North Sumatra Religious Court, among others:

\section{a. Technical Factors}

\section{Limitations of Mediator}

From the many cases that enter the North Sumatra Religious Court while the number of Judges is limited and there is no mediator from outside (North Sumatra Religious Court does not have a list of non-Judge Mediators) so this mediation process adds to the work of Judges, this is what causes the work of the Mediator Judge not maximal. Normally there are two assemblies in a day, then automatically one or two people get a quota for mediation that day, plus in addition to helping mediation the Chairperson of the Assembly and its members also have the responsibility to handle many cases, this is one of the obstacles.

\section{b. Mediation time is too long}

The principle of simple, fast and low cost is a principle that is very easy to say but very difficult to practice. With the length of time in the mediation process which is a maximum of 30 days plus 30 days if the mediation fails, this is not very suitable for the parties that they are determined to divorce. 


\section{c. Non-Technical Factors}

1. Lack of understanding for the parties about the importance of mediation The parties' ignorance of the mediation process. For them mediation is to solve the problem, what is important in the process is the discussion (deliberation), whether the talks are biased or not. Usually the parties are not cooperative to mediation because there have been prolonged disputes and the court is the final culmination of their problem, they follow the mediation process not because of the heart's desire, not because they see a good opportunity from mediation or they see the benefits of mediation. But because of fears their decision will be null and void if they do not follow the previous mediation process.

2. The absence of one party. The presence of the parties to the litigation is very important, often the parties are not present in the mediation process even though they have been summoned appropriately and successively.

In the typical North Sumatra Religious Court Divorce is very diverse including which can be described as follows:

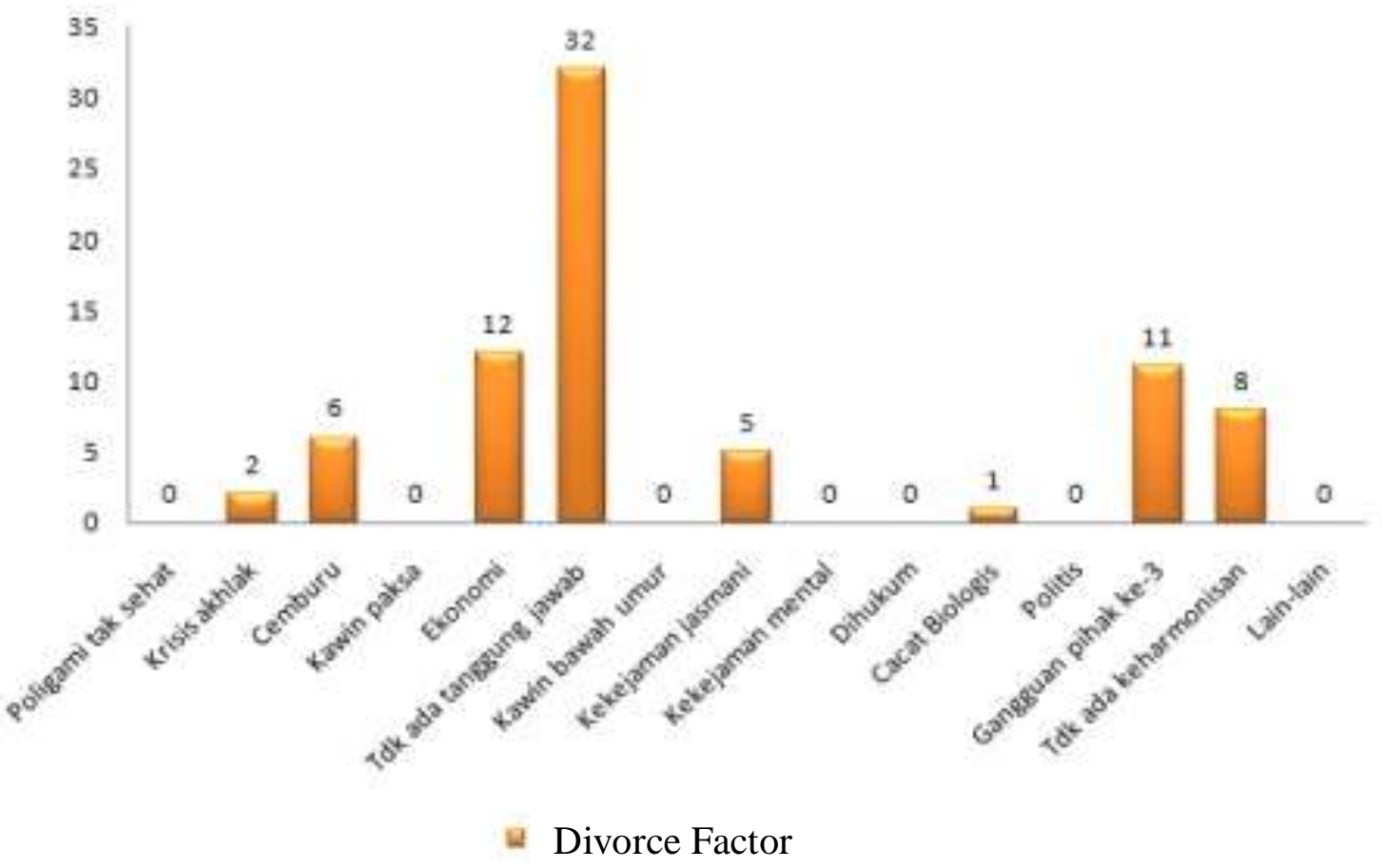

Figure 1. Typical North Sumatra Religious Court Divorce

From the above data it can be seen that the most domonant in the cause of divorce is no responsibility due to drug involvement and so on. It's just that, from the number of cases received at the North Sumatra religious court for 3 years after the issuance of PERMA No. 1 of 2016, only 99 that is, in 2017 there were 31 successful cases, in 2018 there were 39 successful cases, in 2019 there were 29 successful cases, all cases were decided / resolved which could be resolved by successful mediation (contradictory). As for the rest, the verstek verdicts are examined, rejected, revoked, not accepted and crossed out the register. And the successful or successful mediation of 5442 cases that were attended by both litigants was only 99 cases or 1.82. then if it is compared during the 3 years before the issuance of PERMA No. 1 of 2016, it turns out that only 49 cases of cases were decided through mediation of the 
number of cases with 5731. If the percentage is only $0.85 \%$. The settlement of the case is very worrying.

For the similarity of steps regarding the procedure of conducting mediation in the Court, it is necessary to issue more strict and clear rules in the form of revisions. Locally, the North Sumatra Religious Court has determined that mediation is only mandatory when both parties present at the trial.

According to a Judge of the North Sumatra Religious Court that PERMA Number 1 of 2016 concerning Mediation Procedures, if reviewed juridically, the PERMA must be carried out, otherwise this would conflict with article 3 paragraph (3) of Perma Jo. Article 30 HIR and / or Article $154 \mathrm{Rbg}$ which results in a decision violates the provisions of the law governing Mediation in the Court or if it does not take mediation procedures based on PERMA Number 1 of 2016.

Implementation of PERMA Number. 1 Year 2016 in the North Suamatera Religious Court has not been implemented as aspired by PERNA itself, because the mediator in the North Sumatra Religious Court is still small coming from outside the court that has received a Mediator Certificate which is validated by the Supreme Court of the Republic of Indonesia, let alone added the ability Dai's background is very minimal, whereas judges and non-judges as mediators provided by the North Sumatra Religious Court are limited in number and not comparable with cases that go to court, making the mediation event not fully implemented, sometimes even the process of conducting mediation is only a formality so that the case will be decided or determined later will not be null and void

\section{Conclusion}

The implementation of peace in divorce cases in the North Sumatra Religious Court is not significant. In the implementation of divorce case mediation in the North Sumatra Religious Court, many factors influence, among others, technical and non-technical factors. The technical factor is the limitations of the Mediator, namely the absence of a list of nonJudge Mediators here will further aggravate the work of the Judge because of his work being double that is as a Panel Judge and Mediator Judge. So that the work of the Judge mediator is very ineffective and so is the non-judge mediator who must have an official certificate from the Supreme Court so that the training costs are large and the costs of the mediator are not protected by the Regulation

\section{References}

Abdul Manan. (2007). Etika Hakim dalam Penyelenggaraan Peradilan suatu Kajian dalam Sistem Peradilan Islam (Jakarta: Kencana, cet. 1)

Arsip Data Pengadilan Agama Medan Tahun (2009). diambil dari Panitra Muda Hukum Saiful Alamyah S.Ag,MH

Faisar Ananda Arfa. (2010). Metodologi Penelitian Hukum Islam Medan: CV. Perdana Mulya Sarana.

Himpunan Statistik Perkara Peradilan Agama Tahun. (2007). Ditjen Badilag MA RI, Jakarta, 2019.

M Yahya Harahap. (2006). Hukum Acara Perdata, Jakarta: Sinar Grafika.

Moh. Adib Bisri, Terjemah Al-Faraidul Bahiyyah (Risalah Qawa-Id Fiqh), Kudus:

Mukti Arto. (2005). Praktek Perkara Perdata Pada Peradilan Agama, Yogyakarta: Pustaka Pelajar. 
Pagar Hasibuan. (1995). Himpunan Peraturan Perundang-undangan Pradilan Agama di Indonesia, Medan:IAIN PRESS.

R.Soetojo Prawirohamidjojo. (1996). sejarah Perkembangan Hukum Perceraian di Indonesia dan Belanda,Surabaya: Airlangga University Press.

Samir Aliyah. (2004). Sistem Pemerintahan Peradilan dan Adat dalam Islam, Jakarta: Khalifa.

Surya, H,. Et al. (2019). Improving Factors of Divorce Rate in Sabang City. Budapest International Research and Critics Institute-Journal (BIRCI-Journal). P. 104-114

Syahrizal Abbas. (2011). Mediasi dalam Hukum Syari'ah, Hukum Adat dan Hukum Nasional, Jakarta: Kencana Prenada Media Group.

Tim Penyusun. (1997). Ensiklopedi Hukum Islam, Jakarta: PT. Intermansa.

Wawancara dengan Ibu Sri Armaini MH. (2020). di Pengadilan Agama Binjai, Pada Tanggal 19 Juni 